\title{
Absence of fingerprints-congenital milia syndrome
}

INSERM

\section{Source}

INSERM. (1999). Orphanet: an online rare disease and orphan drug data base. Absence of fingerprints-congenital milia syndrome. ORPHA:1658

Absence of fingerprints-cong enital milia syndrome is characterized by neonatal blisters and milia (small white papules, especially on the face) and congenital absence of dermatoglyphics on the hands and feet. It has been reported in two kindreds (one of which contained 13 affected individuals spanning three generations) and in an unrelated individual. Some affected patients also showed bilateral partial flexion contractures of the fingers and toes, and webbing of the toes. The syndrome is inherited as an autosomal dominant trait. 